\title{
Políticas de la falta en el discurso nacionalista contemporáneo hacia el Perú bicentenario
}

Recibido: 15/05/2021

Aprobado: 23/06/2021

Publicado: 31/07/2021

\author{
alexis Patiño-Patroni Palacios \\ Pontificia Universidad Católica del Perú (PUCP) \\ Universidad de California, Davis (UC) \\ patinopatroni.a@pucp.pe \\ https://orcid.org/0000-0003-1471-8198
}

\begin{abstract}
RESUMEN
En los últimos años, los discursos y las políticas de ímpetu nacionalista que han animado procesos de identificación y construcción simbólica en el Perú se han desvanecido ante la emergencia de una crisis múltiple que coincide con las truncas celebraciones del bicentenario. El presente estudio discute algunos momentos contemporáneos de apelación nacionalista, pero analizándolos desde sus transiciones mutuas y entrelazamientos narrativos, a partir del desmontaje de objetos culturales de circulación masiva que enuncian lo nacional desde diversos lugares ideológicos y horizontes afectivos. Haciendo una distinción con los estudios historiográficos del nacionalismo, que se c entran en la discusión entre los enfoques perennialistas asentados en los orígenes ancestrales de las naciones, y por el otro, el paradigma moderno, constitucional y construido de la identidad nacional, me concentro en las estrategias discursivas por las cuales las invenciones nacionales se cimentan en las subjetividades y la opinión pública. En particular, a partir del apego a identificaciones que se sostienen en investimentos psíquicos y que vinculan el deseo y el afecto de los sujetos con la necesidad de asir la experiencia de la nacionalidad.
\end{abstract}

Palabras clave: nacionalismo, representación, Estado, mercado, afecto, deseo, publicidad

\section{The Politics of Lack in The Nationalist Contemporary Discourse towards Bicentenial Peru}

\begin{abstract}
In recent years, the emergence of multiple crisis in the midst of the celebrations of the bicentennial have wither the nationalist discourse and politics that encouraged symbolic national fervor and identity in Peru. This study discusses a few contemporary moments of nationalist appeal, by tackling them from their mutual transitions and intertwining narrative, and by critically dismantling cultural objects of mass circulation that symbolize the nation from different ideological standpoints and affective horizons. By drawing a distinction between the historiographical studies on nationalism, which focus on the debate over perennialist approaches based on the ancestral origins of nations, and on the other hand, the modern paradigm, a constitutional and constructed national identity, I focus on the strategies and tactics through which nationalist fabrications settle in the subjectivities and in the public opinion. In particular, the attachment to identities that are affixed to psychic investments that link subjective desire and affection with the need of experiencing nationality.
\end{abstract}

Keywords: nationalism, representation, state, market, affection, desire, advertisement 
P oco después de la transición democrática (2000-2001), el Perú revivía un momento de optimismo colectivo, y los recuerdos de la década perdida contrastaban con una algarabía colectiva que legitimaba públicamente cómo el modelo entregaba sus frutos. Para finales de la década, a pesar de la crisis económica global, el crecimiento era sostenido y mientras las calificadoras de riesgo y los organismos internacionales celebraban el desempeño del país, la inversión extranjera tocaba afanosamente nuestras puertas. Se redescubría el valor del patrimonio milenario y la biodiversidad, algunos deportes obtenían logros internacionales y la culinaria peruana se nominaba como punta de lanza del orgullo patriótico. En años recientes, luego de la experiencia temporal de gratificación colectiva - la clasificación y participación en Rusia 2018-, la hegemonía ideológica de la Marca Perú y la gastro-política se desvanecen paulatinamente ante un nuevo punto crítico de antagonismo: el quiebre de la representación política y su lumpen-banalización; el develamiento de la corrupción en gestiones regionales; el estallido transnacional del Caso Lava Jato; las consecuencias que desenlazan en la crisis política de noviembre del 2020; el desnudamiento de la precariedad de los procesos burocráticos y de prestación de servicios básicos del Estado republicano en un contexto de pandemia; y la reaparición, en el último proceso electoral, de un clivaje político y cultural que visibiliza nuevas identificaciones representativas en los entornos popular periféricos. ${ }^{1}$

El presente artículo identifica algunos momentos contemporáneos de emergencias nacionalistas, pero analizados desde sus transiciones mutuas y entrelazamientos temporales y narrativos, a partir del desmontaje de objetos culturales de circulación masiva que apelan al nombramiento nacional desde diversos dispositivos discursivos y horizontes afectivos. Primero, explo-

1 La gastro-política expresa cómo el Estado y el sector privado en el Perú implementaron estrategias discursivas y simbólicas, en las últimas dos décadas, hibridando el legado cultural material e inmaterial del país con la retórica de la inversión productiva, como motores exclusivos del crecimiento económico. Se reviven así antiguas formas de fijación de la identidad colectiva, redirigiendo siempre nuevas articulaciones económicas con el resto del mundo, definiendo al país como un destino despensa. En términos de Matta (2019), la gastro-política comprende: "Una serie de estrategias de relaciones internacionales que consisten en presentar la culinaria nacional y la cultura local en general, con el objetivo de ensalzar la reputación del país y fomentar negocios y capitales peruanos en el exterior. La gastro diplomacia comunica una ideología y delinea los contornos de una forma de ciudadanía y sentido de nacionalidad comprometida con el logro de objetivos políticos y económicos [...] se expresa con tres valores incrustados en los contextos neoliberales latinoamericanos: el elogio y promoción de la diversidad cultural, el emprendimiento y la competitividad". 
ro la voluntad de articulación colectiva detrás del simbolismo velasquista, en tanto maquinaria y promesa representativa para construir una política de masas y una cultura nacional-popular. Criterios organizativos extintos, pero nuevamente añorados y disputados en la actualidad. Sugiero cómo el sentido de la acción colectiva se desliza y difumina desde la gubernamentalidad, en tanto herramienta constitutiva del pueblo, atenuándose con la democratización institucional, hasta su apropiación y monopolización, desde las lógicas comunicacionales privadas y la acentuación del automatismo individual. En segundo lugar, analizo cómo el repertorio de la demarcación republicana frente al enemigo externo - discursos tradicionalmente castrenses - va a ser resemantizado desde los imperativos de la comunicación empresarial y publicitaria en el contexto de la gastro-política. Desde ahí, desmonto ese nacionalismo de consumo, expresado en la alianza explícita entre el Estado, el sector privado y las industrias comunicacionales, y que en los últimos quince años han monopolizado las ideas sobre la nación desde los criterios económico-culturales de la globalización neoliberal. Finalmente, a modo de conclusiones, abordo las posibilidades del legado del proyecto bicentenario y su conducción académica, así como su excesivo apego al paradigma unitario de la nación y las categorías tradicionales del diseño institucional liberal-moderno.

Esta mirada de proceso me permite revisitar una distinción crucial pero poco abordada en los estudios sobre los nacionalismos contemporáneos, a saber, entre los enfoques perennialistas que resaltan, por un lado, los orígenes ancestrales (inmemoriales) de las naciones (étnicos, dinásticos, lingüísticos, etc.), y, por el otro, el carácter moderno y construido de la identidad nacional atado a las categorías políticas liberal-constitucionales (Smith $2000,61)$. A diferencia de trabajos recientes sobre los discursos celebratorios de la nación y el denominado branding nacional (Canepa 2013, Canepa y Lossio 2019, Canepa y Lamas 2020), centrados en el discurso simbólico y en sus invitaciones performativas, me avocaré a una lectura que acentúa los motivos por los cuales estas invenciones narrativas se reproducen y sedimentan con perdurabilidad. Por ello, exploro cómo el apego a las identificaciones nacionales se puede comprender desde el estudio de las estrategias de investimentos psíquicos y libidinales que vinculan el deseo y el afecto de los sujetos con esa necesidad simbólica y performativa de asir la experiencia de la nacionalidad. 


\section{Del Estado como promesa constitutiva del pueblo a su vaciamiento cohesivo}

En el mensaje a la nación con motivo del sesquicentenario de la independencia, Velasco articulaba elocuentemente el carácter poscolonial de la nación. A pesar del conservadurismo de la comisión encargada del proyecto, se resaltaba el carácter elitista de la conducción intelectual y política del proceso independentista y cómo las cúpulas criollas, desenganchadas de los procesos populares, reprodujeron formas culturales y económicas de opresión. Más allá del debate historiográfico abierto por ese evento de impulso nacionalista, se asume una postura práctica de interpretación e intervención de un presente antagónico y la necesidad de enunciar las perspectivas subalternas y sus posiciones existenciales, desde una mirada nacional que debía construir una interdependencia armónica (o agónica) entre las partes sociales. Desde la vuelta a la democracia en 1980, el sistema político y el aparato estatal herederos del liberalismo criollo no han podido acercarse a las condiciones situadas de las gentes y comunidades más variadas, tanto para recoger sus tradiciones y prácticas propias, como para plantearles visiones ético-políticas con el fin de generar procesos de organización y representación enmarcados en un equilibrio básico que parta de una sujeción legítima de los individuos a la ley. En términos de Portocarrero (2004, 231), es el reto de dialectizar las memorias para negociar permanentemente el conflicto inherente y "consolidar autoridades consensuadas que signifiquen tanto la prevalencia de la ley como de un sentimiento de comunidad, de reconocimientos mutuos".

En el impulso movilizador que esbozó el velasquismo: una intermediación participativa, de acciones directas, encausadas desde arriba, o inclusive propiciadas en reacción al propio régimen, se prefiguran formas fructíferas de politicidad en la sociedad civil y popular bajo el horizonte siempre provisional de una convivencia nacional dirigida desde el aparato estatal con el fin de legitimar la autoridad y abandonar el autoritarismo, hegemonizando estructuras comunes de sentimiento entre la pluralidad de situaciones sociales. Sin negar el proceso independentista, Velasco enfatiza su carácter inconcluso y una impronta corporativa localista, clasista y racista, que da continuidad a la subordinación humana. Desde ahí, su llamado a la cogestión no se acota al mundo subalterno: indígena-mestizo-rural, los nuevos barrios y comunidades urbanas-migrantes, sino que se incorpora explícitamente el rol de los profesionales, las clases medias y los empresarios urbanos, en un espíritu que 
tal vez haya sido el último intento por construir una sedimentación simbólica totalizante y una infraestructura cohesiva, que hubiera servido tal vez, de sustento a las posteriores homogenizaciones ciudadanas y de sus diferencias.

En la transición entre las imágenes 1, 2 y 3 que aquí se presentan, se vinculan objetos culturales provenientes de temporalidades y lugares de enunciación ideológica disímiles. Sostengo que en ese entrelazamiento se da cuenta del abandono y el desvanecimiento de las políticas estatales hacia la promoción del espacio popular y ciudadano, y cómo este impulso puede ser revisitado críticamente en la actualidad para disputar nuevos roles e intensidades en la relación entre el Estado y las gentes. ${ }^{2}$ Como toda la serie de Jesús Ruiz Durand para la oficina de reforma agraria, la imagen 1 expresa la confluencia entre las prácticas situadas del campesinado, su condición de explotación y un proceso de transformación adherido a un proyecto colectivo que nombra lo político como una acción relacional de identificaciones y equivalencias entre las vanguardias dirigentes y el pueblo. Los sujetos son plenamente en la medida en que asumen este proceso circular de constitución, reconociendo sus propias condiciones de existencia e involucrándose para su modificación. Un proceso fiel de representación sería aquel en el que la voluntad del representado es transmitida con precisión y literalidad al representante, quien se limitaría a un rol espejo, una suerte de transmisor pasivo que no filtra, recrea o complejiza dicha voluntad. En términos de Laclau (2005), sin embargo, en el tiempo de la política de masas, la formulación que hace el representante (venga de los partidos o del Estado) tiene un rol estructurante y articulador constitutivo, que siempre añade algo a los intereses y motivaciones de los representados. Es en ese plus en donde se tejen las identidades políticas, sobre todo ahí donde la sociedad civil/popular - el espacio social extraestatalestá disperso, subordinado, excluido de servicios básicos, educación pública de calidad, sin acceso al conocimiento, la información, los discursos técnicos y analíticos, y alejado del ejercicio de los derechos políticos, normalmente reservados a los canales letrados e institucionales.

2 La distinción entre espacio popular y ciudadanía es pertinente en la medida que denota formas de organización, comunicación y politicidad disimiles, asemejando lo que Chatterjee (2007) ha llamado la separación de la categoría de sociedad civil de la de "sociedad política". La sociedad civil es portadora de una serie de derechos, demandas, intereses compartidos que pueden ser articulados frente al Estado mediante una acción cívica o legal. Por el otro lado, la sociedad política está en relación con las poblaciones excluidas del proceso de modernización de la nación, con amplias capas sociales que viven y negocian con las autoridades en sus propios términos y que no recurren necesariamente a los causes institucionales de intermediación. 
Al interrumpir la hegemonía tanto material como racial y cultural del tutelaje gamonalista, el régimen constituye ejes de mímesis y metonimia, dentro de las cuales la figura de Túpac Amaru funcionará como significante de condensación para las identificaciones populares, indígenas y mestizas, definiendo no solo un canal de resarcimiento moral frente a la brutalidad colonial, sino también la posibilidad de generar encadenamientos novedosos al estilo catch all people (Cant 2017, Leonardini 2009). Ruiz Durand (2018) ha expresado cómo sus trazos originarios de la imagen de Túpac Amaru II serían recreados por los actores populares, dándole formas propias a las versiones finales de los afiches, los que fueron inspirados en registros fotográficos reales de rostros y sujetos situados regionalmente, y que a su vez eran impresos y distribuidos en razón de 50 y en algunos casos 100 mil ejemplares. Mientras que las obras de arte se limitan a presentarse como una unidad monádica y esencial, la insolencia de la reproducción masiva y serializada de los afiches velasquistas des-sublima su condición áurica. Sin eliminarla completamente, la encarniza en la visceralidad de subjetividades portadoras de antagonismos básicos, que comienzan a ser cargados políticamente, tanto desde las invitaciones concretas del régimen (las reformas materiales y sus procesos organizativos) como desde las simbólicas (procesos de construcción de significados y redes de empatías y solidaridades).

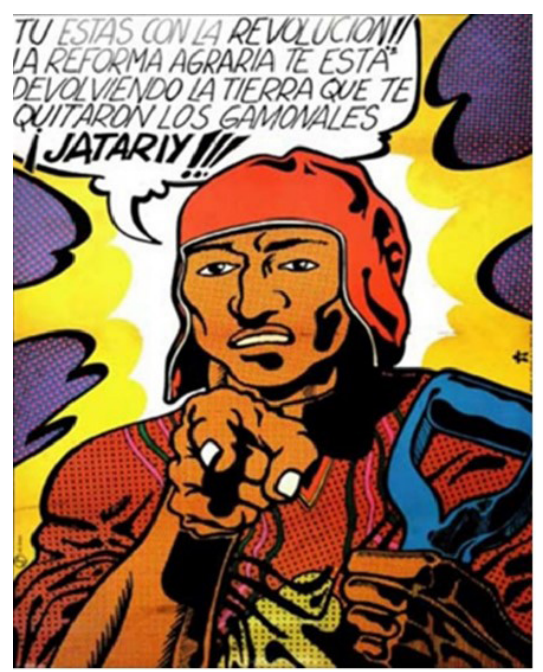

Imagen 1. Afiche de la Reforma Agraria, sin título, realizado por Jesús Ruiz Durand.1969. 


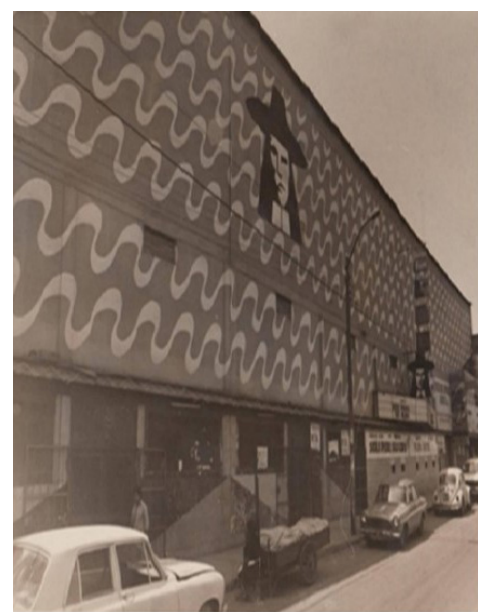

Imagen 2. Fotografía del cine coliseo Tupac Amaru, publicado en Crónica Viva.

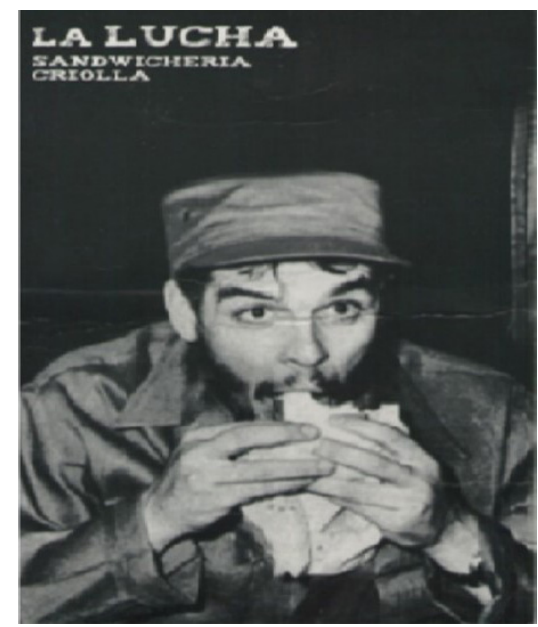

Imagen 3. Fotografía del Che Guevara publicada en el encarte de la Sanguchería "La lucha".

La imagen 2 nos muestra el cine Túpac Amaru en el distrito de Comas. Construido en 1971, en pleno proceso revolucionario, el trazo arquitectónico original de esta empresa privada exhibe en su fachada el diseño de Ruiz Durand, añadiendo una nomenclatura propia para el establecimiento: centro social, cine-coliseo. Con la consolidación de los nuevos distritos migrantes de Lima, se apertura una nueva categoría de cine que rompía con la típica 
diferenciación entre los grandes teatros del centro de Lima y los barrios urbanos, y que a pesar de su naturaleza privada (económica-familiar) se va a identificar con el carácter popular y el proceso de reforma general del régimen y sus imaginarios. Paralelamente a la formación de estos espacios privados de traducción cultural subalterna, en 1972 un grupo de cineastas e intelectuales liderados por Armando Robles Godoy transmite al régimen la necesidad de interrumpir la mímesis perversa que el colonizador — el cine de Hollywoodhabía solidificado con la audiencia nacional. Surge así la única ley cinemato gráfica de la época republicana capaz de generar una producción interna estable (1972-1992) frente al gran mercado simbólico de Hollywood. La ley no regulaba explícitamente lo que se veía habitualmente en los cines, pero sí intentaba recuperar la capacidad de emancipación cultural y estética, proceso ahora patrocinado por un fuerte compromiso estatal. La Ley 19327-1972, "Ley de promoción de la actividad cinematográfica", establecía que antes de la exhibición de las películas comerciales foráneas todos los teatros del país debían exhibir obligatoriamente un cortometraje peruano. En el período de su vigencia, se produjeron aproximadamente 1500 cortometrajes y 60 largometrajes, una cifra inédita para una industria cinematográfica históricamente débil. La ley se basó en dos mecanismos básicos: i) la exhibición obligatoria de películas peruanas, y ii) el impuesto de taquilla. Luego de lograr filmar de manera privada un cortometraje, los productores locales postulaban sus proyectos a la Comisión de Promoción Cinematográfica COPROCI, quien evaluaba las producciones, nunca exentas de cierta censura. Se les emitía un certificado de exhibición, y la película tenía derecho a ser proyectada durante toda una semana por un período de un año en todos los cines del Perú. Los largometrajes, por obvias limitaciones temporales, debían rotar en los circuitos cinematográficos obligatoriamente durante al menos una semana al año. Por su parte, el impuesto a la taquilla aseguraba que los productores de películas recibieran un porcentaje del costo de la entrada a través de una tasa municipal. El diez por ciento del costo de cada boleto de una película extranjera se quedaba en el municipio del lugar donde estaba ubicado el cine, y el productor de la película recibía un $1 \%$ de ese total. ${ }^{3}$

La ley del cine de Velasco fue de hecho solo un pequeño ejemplo indirecto de financiamiento estatal, planificación pública e interpelación cultural. De hecho, en el apogeo de la revolución, el cine y la producción audiovisual aún

3 Para un recuento mayor de este proceso, véase Bedoya (2019). 
no eran plenamente entendidos por el régimen como dispositivos simbólicos y educativos. El caso del cine-coliseo Túpac Amaru es relevante en la medida en que nos muestra cómo la interacción entre iniciativas de mercado espontáneas y una gran comunidad distrital en vías de politización podía resignificar una práctica de consumo y entretenimiento en rituales de asamblea que propiciaban encuentros que iban más allá de la experiencia del visionado del cine, y donde el afecto y el deseo estético emanado de esa experiencia permitía a su vez la construcción de identidades de barrio situadas y que además eran acogidas en un espacio arquitectónico, material y funcional a sus formas de organización. A diferencia de los cines del centro de Lima o de sus distritos, los materiales de su construcción "presentaban un lenguaje arquitectónico sencillo, sin ornamentación, con la única funcionalidad de optimizar el número de espectadores, presentando en sus plateas y balcones, bancas continuas de hierro y madera empotradas al suelo" (Mejía 2009, 248). Asumiendo en su fachada el retrato de Túpac Amaru II como motivo, el teatro privado reafirmaba inconscientemente su carácter antioligárquico, haciendo explícita la expectativa que generaba el cine en esta zona emergente de Lima, y cómo esta actividad cultural gregaria servía al mismo tiempo como espacio de identificación mutua y exploración de ideas políticas clasistas, independientemente del intento totalizador del régimen del campo popular, a través de sus instituciones y políticas.

En diciembre de 1992, después de la publicación del paquete de reformas neoliberales, el Gobierno de Fujimori intervino la ley, anulando los artículos antes mencionados, e inhabilitando en la práctica su poder real para asegurar la exhibición y el financiamiento permanente de las producciones cinematográficas nacionales. Hoy, casi treinta años después de la derogación de la ley, cuando se plantea una nueva forma de proyecto de apoyo estatal de este tipo, los tecnócratas del Ministerio de Economía y el consenso económico neoliberal argumentan que estas formas de financiamiento público atentan contra la Constitución: hoy en día las cadenas de multicines privados no pueden estar obligadas a contratar con otros actores privados (productores de cine locales), y los impuestos deben ser destinados a las entidades públicas o las arcas del Estado, y no pueden ser desviados a beneficiarios privados (productores locales). Según Bedoya, la fenecida ley fue crucial en la medida en que creó una cohorte de directores nacionales que aprendieron los tecnicismos de la producción, dirección y exhibición cinematográfica, y a la vez modeló por primera vez el gusto de un público nacional, que se va a reconocer reflejado 
en la pantalla, desde las producciones que comienzan a enfocarse en sus propias realidades y problemáticas situadas: el trabajo, la hacienda, la migración, la racialización, la guerra interna, etc., y que van a delinear un "nosotros" cinemático.

El declive del régimen y la transición democrática permite expandir libertades formales e institucionales, invirtiendo paradójicamente el acercamiento relativo que se había tejido contradictoriamente entre el aparato estatal y la gente. El sistema de partidos retoma el vínculo representativo, pero descuidando el acercamiento mediador del Estado y su importancia en tanto arena y aparato de reconocimiento y disputa. Paralelamente, varios procesos internos y transnacionales alimentan el debilitamiento, desprestigio y abandono del Estado como variable constitutiva de la política: la propia ineficiencia macroeconómica y las consiguientes crisis fiscales e inflacionarias, el resquebrajamiento de los partidos de masa, las nuevas migraciones, los accesos al consumo y la tecnología, las nuevas lógicas de anonimato urbano, los emprendimientos económicos familiares, los desgarramientos de la violencia política, el desplazamiento y el abandono. Así, significantes como Estado, partido, espacio e interés público son cada vez más emparentados a un terreno de ineficiencia estatal y corrupción, arcaísmo colectivista, ideología como falsedad, anulación de las libertades individuales. Estos elementos van a servir de amortiguación y legitimación del paquete de reformas neoliberales y la lógica antipolítica, la que va a delegar a las tecnoburocracias profesionales la capacidad de gobernar, pero sobre todo a sus agencias comunicacionales la tarea de justificar la política económica ante una población que transita de la condición ciudadana a la lógica de una gran audiencia pasiva. En este sentido, paralelamente al desmantelamiento material de su estructura, el rol cohesivo del Estado se suspende, limitándose a una función de administración gerencial y técnica. Como indica Jesús Martín Barbero (2009, 37), el repliegue del "Estado latinoamericano ha sido suplantado por la autoridad de la ciencia macroeconómica, la cual no solo relegó la política a un lugar subalterno en la toma de decisiones, sino que ha contribuido grandemente en nuestros países al vaciamiento simbólico de la política, esto es a la pérdida de su capacidad de convocarnos y hacernos sentir juntos". Tanto la cesión de poder técnico (poder de diseño, de formulación y de aplicación de políticas concretas), como la entrega de poder de articulación simbólica, es decir, la libertad operativa para construir narrativas y percepciones comunes, son monopolizados ahora por los agentes mediáticos y los intereses empresariales, con la finalidad de iden- 
tificar la eficiencia y la grandeza de la nación con la hegemonía de la sociedad en un contexto de capitalismo informacional, flexible y biopolítico.

La imagen 3 enfatiza este cambio de énfasis histórico y la desmaterialización de las lógicas de intervención estatal, interés público nacional y organización colectiva. En el encarte publicitario de la sanguchería La Lucha, la imagen del Che Guevara es asimilada a la lógica del consumo y su disfrute desde la identificación con el oficinista moderno, que según los propietarios de la franquicia, conforman su público objetivo de targeting. El discurso de identificación publicitaria se relaciona a la vida cotidiana de estos asalariados subordinados, pero también a la historia de sacrificio y éxito de los propietarios con la apertura de su nuevo local del parque Kennedy en Miraflores. La imagen del Che Guevara ha sido recreada y banalizada en diversos soportes de mercadeo simbólico: accesorios, souvenirs, polos, llaveros, stickers, gorras, etc., domesticando sus connotaciones transformativas y contraculturales (Heath y Potter 2005). Luego, al dar vuelta al encarte uno se encuentra con una cita interpeladora de Miguel Ángel Cornejo (2009), gurú de culto del mundo de la administración empresarial, la motivación, el liderazgo y promotor de las técnicas más variadas de programación conductual:

\begin{abstract}
A todos los líderes, padres y maestros, religiosos, empresarios, etc., los invito a reflexionar y renovar su misión de cada día para forjar la sociedad que deseamos para nuestros hijos, a través de LA LUCHA, para hacer de cada una de sus empresas un centro de producción de alta calidad. Dedicado a la formación de seres superiores. Para tener una nación de calidad se requieren hombres y mujeres que vivan intensamente el compromiso hacia la excelencia.
\end{abstract}

De esta manera, anverso y reverso se asimilan ahora en un mismo tiempo discursivo. Los buenos deseos para la sanguchería vinculan la grandeza de la nación a la técnica de autoproducción emprendedora. Es en ese imperativo en donde los peruanos podrán convertirse en "seres superiores". El personaje es arrebatado de su temporalidad histórica y los condicionamientos que le daban sentido a su búsqueda política. Las idealizaciones del justiciero social y la apuesta popular revolucionaria son ahora signos decorativos que quedan irónicamente subordinados a la intencionalidad del coaching empresarial y los guiones subjetivos de una sociedad que debe gerenciarse. No obstante, los mandatos implícitos de la postal nos recuerdan que el sujeto no es tan libre como parece, en la medida en la que la programación conductual (en busca de la excelencia, del éxito, a través del consumo) parece quedar obedientemente 
subordinada a una acción robótica, una economía mecánica de la repetición que se expresa en la imagen congelada e irreflexiva del protagonista, quien mastica inacabadamente guiado por una fuerza externa a él. En términos psicoanalíticos, la condena de la repetición expresa el deseo humano en tanto una búsqueda perpetua que se puede relacionar a la lógica libidinal del sujeto, que apunta a una satisfacción —imposible — que siempre termina por extinguirse y trasladarse a otros objetos parciales/temporales, y que jamás puede alcanzar la completud. En el contexto del capitalismo de consumo y su variante nacionalista en el caso peruano, el deseo por asir la nación se sostiene "mediante la dialéctica de la falta y el exceso; a fin de conservar su atractivo, la promesa del exceso descansa sobre la renovación continua de experiencias de la falta" (Stavrakakis 2009, 271).

\section{Esencia y resto nacional: de la visceralidad originaria, al simulacro del antagonismo fronterizo}

Cuando en pleno proceso de consolidación del modelo neoliberal irrumpe el discurso nacionalista del humalismo en la opinión pública, sus apelaciones a orígenes étnicos bajo una retórica de violencia nos recordaban la racialización y pauperización del tejido popular, particularmente expresadas por el maltrato al componente humano del Ejército peruano: juventudes indígenas mestizas, mestizos populares urbanos, posiciones y destinos sociales de descarte a la punta de los fusiles patrios. Sin embargo, rápidamente la intensidad del recurso de la opresión racial, el entreguismo y la dependencia frente al capital imperial extranjero se va a contrastar con la desarticulación de su disperso movimiento de bases y una inconsistente lógica política. El posterior triunfo electoral del 2011, percibido por los sectores mejor integrados al mercado como un hecho apocalíptico para las condiciones del sistema vigente, evidenciaría cómo la temida radicalidad nacionalista cedería rápidamente a la necesidad práctica de gobernar, y la retórica racial-marcial del etnocacerismo sería absorbida por las políticas neoliberales de carácter económico-cultural que el régimen de Toledo había promovido - y el de García potenciado-, y que a su manera comenzaban a fortalecer ciertas autoestimas y deseos de comunalidad en una ciudadanía-audiencia. Sintomáticamente, los investimentos afectivos del humalismo inicial se van a deslizar hacia el repertorio discursivo de las comunicaciones empresariales, el sector estatal turístico y las agencias 
publicitarias, que ahora van a resignificar los binarismos destructivos como fuente productora de identidades sociales.

Un punto de partida significativo para periodizar este giro es la creación de la Comisión Nacional de Productos de Bandera (COPROBA), encargada de posicionar empresas, productos y servicios peruanos en el mercado internacional. Su plan estratégico de exportaciones 2003-2013 basaba su eje central en recursos de nombramiento y significación institucional de los productos de bandera, aquellos bienes naturales o mercancías asociadas a la "calidad autóctona", representando una suerte de autenticidad peruana. PromPerú (2009), lo manifestaba de esta forma:

Estos productos poseen características únicas y especiales derivadas de nuestra geografía, clima e identidad; propia de nuestro contexto, como de la ancestralidad de nuestra cultura. [...] Son sabores, olores, texturas, formas y colores que evocan sentires que no solo satisfacen necesidades de comida, vestido o arte; sino fundamentalmente nuestro espíritu. Ese espíritu amigable, acogedor, sincero, y de hermandad que llevamos todos los peruanos, fruto de la riqueza que existe en nuestra tierra.

De esta manera, la nacionalidad es constituida desde ciertas condiciones naturalizadas, aptitudes y sentidos morales, que inclusive hacen referencia a la interacción social e histórica, y cuya connotación contingente y antagónica no va a ser reprimida, desmentida ni eliminada, como normalmente suele editar el poder comunicacional. Por el contrario, se va a identificar el conflicto y el dolor afectivo por aquello de lo que se carece colectivamente para activar, desde la falta, una performance rehabilitadora — sanadora en términos de la cura psíquica- que recombina una serie de elementos desde el eclecticismo del bricolaje como técnica de sobredeterminación de una realidad nueva y abierta al futuro. ${ }^{4}$ A partir de guiones de prácticas y disposiciones afectivas que deben ser aprendidas, ensayadas e internalizadas, se va promoviendo una fidelidad conductual y cognitiva, un "hacer", o un imperativo performativo que debe desenvolverse con programación y disciplina. Estas estrategias de comunicación simbólica van a

4 La creatividad discursiva al estilo del bricolage — la rearticulación de retazos y partes - no nos debe remitir a la idea de un ángel creativo, un ingeniero-demiurgo que crea y ordena la realidad desde la nada. Esta siempre implica una alienación, Las empresas y sus publicistas, al nominar la nación, ocultan la posición particular e histórica desde donde nombran, para identificar su posición de enunciación con un lugar mito-poiético privilegiado y autónomo, y dada esta investidura, los medios publicitarios se sienten en libertad para resaltar lo que se quiere de una peruanidad ideal y excluir aquello que se desea velar o purgar. 
estar presentes en distintos rubros productivos y comerciales: las industrias textiles y sus cadenas del algodón y el mercado de camélidos, el café, las cerámicas de Chulucanas, los espárragos, el pisco, la lúcuma, la maca y la gastronomía en general. Las guías de acción para narrativizar las campañas de difusión de estos productos estuvieron basados en el Plan Estratégico de Identificación DS. 0252004 de PromPerú, que implicaba la articulación y coordinación multisectorial a través de talleres de ventas y estrategias publicitarias simbólicas para escuelas, hoteles, profesionales del sector (barmans, sommeliers, operadores turísticos, artesanos, tripulaciones aéreas, prensa y opinión pública en general, etc.). Estas articulaciones de política pública, que fueron el antecedente de la construcción de la Marca Perú y sus diversos spots documentales, van de esta manera construyendo una lógica de la peruanidad en tanto un menú que debe ser desplegado para un gran "otro", en donde la nación es sustancializada desde una economía del mito. Para Barthes (1999, 179), el mito:

No niega las cosas, por ejemplo, algún carácter nocivo de la peruanidad o algún proceso histórico o social traumático. Todo lo contrario «su función es hablar de ellas, simplemente las purifica, las vuelve inocentes, las funda como naturaleza e identidad, les confiere una identidad que no es la de la explicación, sino de la comprobación [...] Al pasar de la historia a la naturaleza, el mito efectúa una economía: consigue abolir la complejidad de los actos humanos, les otorga la simplicidad de las esencias, suprime la dialéctica $[\ldots]$ organiza un mundo sin contradicciones puesto que no tiene profundidad, un mundo desplegado en la evidencia, funda una claridad feliz: las cosas parecen tener significado por sí mismas.

Sin embargo, luego de nominar mitológicamente tanto los rasgos afirmativos y nocivos de la peruanidad — es decir, la forma simbólica que adquieren las identificaciones nacionalistas: leyes semióticas, contenidos discursivo-performativos-, la argumentación publicitaria necesita ir más allá para solidificar el apego a la nación y sus entramados narrativos. Por ello, para cerrar el círculo discursivo que tiende a la esencialización — una clausura al interior de la nacionalidad-, los ingenieros comunicacionales deben tocar la "herida narcisista" y manipular el vínculo psíquico que relaciona a los sujetos y su experiencia de la nación como un objeto de deseo primordial, como aquel que nos apega subjetivamente con la madre, por ejemplo. Un camino invariable de los nacionalismos es el reconocimiento de que la esencia nacional añorada solo puede hacerse geológica ante la confrontación de un opuesto externo, un enemigo antagónico, y por lo general fronterizo territorialmente. La cul- 
tura castrense ha expresado comúnmente esta lógica que además debe hacer siempre presente — desde la memoria, la educación o la opinión pública一, esa otredad violenta e insoportable — una negatividad - que en realidad se hace constitutiva del propio discurso de afirmación nacional. Entonces, en el contexto de apertura económica de ansiedad por el reconocimiento nacional, los nation builders del sector privado entendieron claramente la necesidad de re-semantizar la falta, el sufrimiento y dolor nacional para poder intentar la simbolización propia, pero ya no desde el discurso de la eliminación material del "otro" nacional, sino desde la competencia en el terreno del comercio internacional como nuevo escenario ontológico y epistemológico. Veamos un ejemplo de lo anterior para el Perú desde el análisis de la batalla simbólicocomercial con su némesis: Chile, significante que debe ser entendido como objeto colectivo extra-nacional, que dada su condición victoriosa y opresiva en nuestro vínculo de guerra y violencia, representa un agente simbólico de permanente sustracción de nuestro goce y completud nacional.

Cuando Chile logró patentar la denominación de origen del pisco en los fueros internacionales, se generó en el Perú una dura reacción de la prensa y el sector empresarial destacando el carácter pusilánime del empresariado nacional. No se tenían las herramientas para estar a la altura de un nuevo y acelerado contexto de globalización comercial, mucho menos se contaba con las competencias simbólicas para salir del etiquetamiento tercermundista de atraso que se había hecho del Perú desde el primer mundo, dada la imagen sostenida de convulsión social, económica y política del país hasta la llegada del nuevo milenio. Había en las clases empresariales un fuerte complejo o sentimiento de "correr por detrás", de "estar tarde" y en desventaja frente a nuestros pares fronterizos, quienes podían reforzar los etiquetamientos negativos del carácter peruano asumiendo una clara posición de poder y superioridad histórica frente a nuestro país (Herzfeld 1991).

La imagen 4 muestra la reacción de un grupo de comunicadores y hacedores de política comercial frente a la apropiación de la denominación pisco. Allí se presenta un frondoso ramillete de uvas asemejando el continente sudamericano. En el espacio del territorio chileno, las uvas han sido arrancadas, quedando solamente el raspón. En el océano Pacífico, se lee la frase "Chile, despídete del Pisco". Así, son los empresarios peruanos apoyados por un aparato estatal de comunicación y por los medios privados (agencias de sondeo, marketing, publicidad, televisión y radio), los que hacen una nueva declaración de guerra, enmarcada en la lógica de la competencia por el mercado 


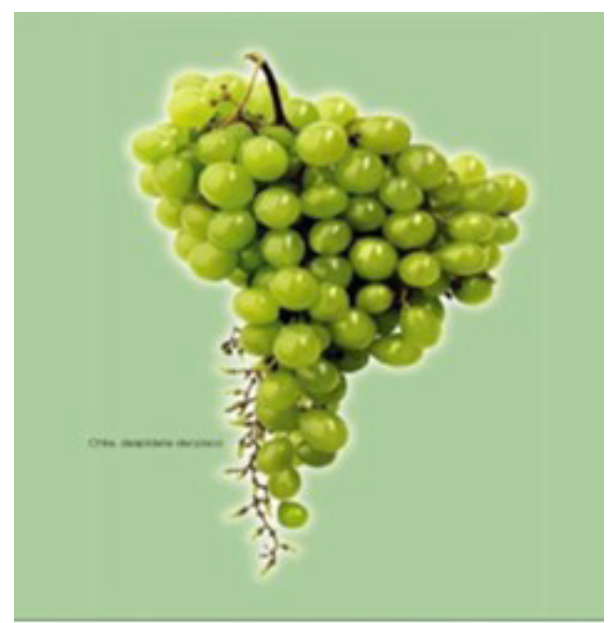

Imagen 4. Representación de Sudamérica elaborado por la empresa Toronja, Comunicación Integral. 2002.

internacional. La condición barrada del significante Chile, una condición impedida de acceso, participación o representación, está claramente sugerida por el raspón en tanto ramillete seco e inerte, un territorio desértico y silenciado, imposibilitado de dialogar con sus pares sudamericanos.

Un elemento central en las narrativas simbólicas que acompañaron estas campañas parte del realce de la superioridad cualitativa del pisco peruano frente al chileno, el cual era evaluado como un aguardiente barato. Pero en realidad, este contraste es una expresión particular de un constructo ideológico que sugería que los productos chilenos en general carecían de originalidad, textura y sabor (de cierta alma). Asimismo, se activa y refuerza la idea de que lo chileno no posee tradiciones locales que le den un mito orgulloso de fundación, o una historia social sin referentes ancestrales, milenarios u orígenes étnicos sobre los cuales construir la cultura nacional. El raspón desértico, en tanto territorio y soberanía chilenas, también nos puede remitir a su carácter artificial de nación creada sobre el vacío, inventada por las tradiciones políticas foráneas (el liberalismo), denotando la ausencia de una fuente material, espiritual y afectiva, que en el caso del Perú es frondosa y obedece a la celebración estratégica —orientalizada - del legado inca y pre-inca (Méndez 2000), En este sentido, el ludismo del argumento también puede sugerir el carácter alienante del liberalismo chileno, una disposición europeizante, racional, ordenada, dispuesta hacia el futuro, pero que a diferencia del Perú carece del sustento maternal de la tierra, sus raíces y cimientos de estabilidad étnica e histórica. 


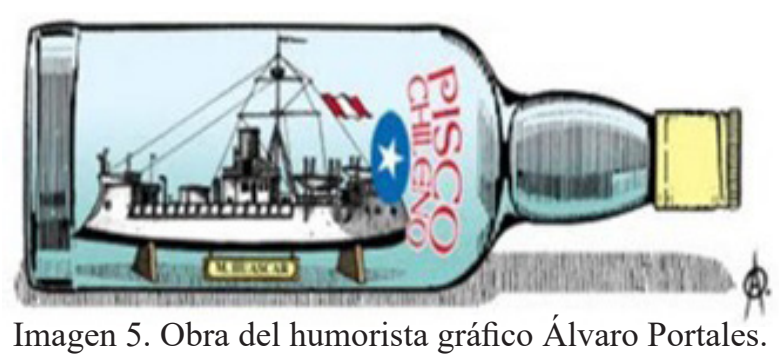

En la imagen 5, una reproducción del monitor Huáscar es aprisionada dentro de una botella de pisco chileno. La imagen evoca cómo el Perú, en tanto cadena de significantes colectivos, no puede separarse de su relación de opresión afectiva con Chile debido a la pérdida del conflicto. Al encapsular el emblema de triunfo y honor peruano de la guerra, se nombra la carga vejatoria de nuestra condición dominada hacia el país del sur, recreando aquello que civilizatoriamente es tramitado mediante los cauces institucionales —en ese momento, Perú y Chile se encontraban discutiendo un asunto limítrofe a través del derecho internacional público-. En suma, para los peruanos el significante Chile no es en realidad el opuesto, o la negación (anuladora) del significante Perú. El significante Chile es parte constitutiva del significante Perú, es un resto abyecto que compone una incompletud básica de la peruanidad: un terreno imaginario (de encuentro con los otros) que al ser esencial y doloroso al mismo tiempo quiere ser expelido, en tanto variable desechable, dada su condición excrementicia de lo nacional peruano. ${ }^{5}$

Es claro cómo la cultura publicitaria en el Perú se ha apropiado de las estrategias de simbolización de la falta al interior de sus narrativas voluntaristas sobre la nacionalidad. Por ello, la publicidad y la comunicación contemporá-

5 Carmen Mc Evoy, en su libro Armas de persuasión masiva, retórica y ritual en la guerra del Pacifico, ha trabajado extensamente los diversos discursos de configuración mental que fueron construidos por el Estado chileno de 1879, a través de militares, políticos, curas y periodistas, para producir un consenso ideológico en la población chilena acerca de su superioridad moral frente a sus rivales. A partir de símbolos, arengas, rituales y acontecimientos, se construyó una imagen propia, asociada al poder, la fuerza, la organización, la civilización y la victoria. Al mismo tiempo, se dotó al rival de las perversiones, barbaridades y vicios del caso. Más allá de que el factor simbólico haya sido un elemento secundario en el triunfo chileno, la idea central del texto es que esta red de significaciones favoreció a la solidificación de la moralidad colectiva y la identificación nacional en ese país (Mac Evoy 2010, 17). La peruanidad es dotada de un alma incivilizada, deseosa de un orden por subyugación, mientras que el espíritu chileno es asociado a la racionalidad de la masculinidad occidental, heredero más ferviente del liberalismo político del XIX, abrazado y venerado por sus precursores e ideólogos nacionales. 
neas no solamente deben ser entendidas como espacios discursivos desde los cuales se generan necesidades y deseos superfluos en la gente; quedarse atado a ese paradigma crítico discursivo de falsa conciencia — que desmiente a la publicidad por construir a las audiencias desde el embuste - no permite describir y comprender las proyecciones del nacionalismo mediático peruano, el cual ha estado anclado en la exploración de la escisión constitutiva de los sujetos que el psicoanálisis muestra con claridad, y que le ha servido como una forma para organizar los deseos y sentimientos de las personas, minimizando o suspendiendo estratégicamente las mediaciones racionales (conscientes) del consumidor-ciudadano. Como lo ha referido Qualter (1991, 89), "mientras la práctica publicitaria se ve obligada a tomar en cuenta el carácter no racional del deseo, la teoría publicitaria sigue difundiendo la filosofía liberal de los consumidores racionales informados". Así, podríamos afirmar que el despliegue de estas estrategias de totalización nacional incorpora inconscientemente, en ellas mismas, las limitaciones e imposibilidad de su proyecto unificador y de clausura de los antagonismos. La publicidad va a tratar de anticipar y resignificar aquello que descompleta su narrativa homogenizante, asumiendo la fatalidad histórica como un momento necesario de imperfección que haría posible la rearticulación colectiva y nuevas transformaciones sociales en un futuro a construir. Pero entonces, inclusive el carácter profundamente ideológico del nacionalismo publicitario, atado al crecimiento económico, la excelencia comercial y la programación biopolítica — performativa disciplinarpara afianzar el utilitarismo competitivo, se va a desplazar hacia el terreno de la utopía, como se verá en la siguiente sección.

\section{Entre el consumo performativo, la pasteurización multicultural y los disfraces afectivos de comunalidad utópica}

Hay días en los que desconfío de tanto chullo en pasarela fashion, de tanto cuy servido en porción gourmet, de tanto bordado ayacuchano en zapatillas de marca, de tanto chill out con valsecito y cajón, de tanto orgullo porque nuestra bandera haya sido elegida la segunda más bella del mundo, de tanto libro ilustrado sobre nuestros portentosas recursos naturales y culturales, de tanto Tongo en Gótica, de tanto interés por el turismo interno, de tanto portafolio de fotógrafo-peruano exitoso en el mundo retratando a flaquitas europeas entre vendedoras de cuero de chancho en los pueblos jóvenes de Cusco.

RAFo LeÓN, Somos N. ${ }^{\circ} 23$ (2008) 
En pleno apogeo del discurso publicitario nacionalista, la cita precedente sospechaba los procesos de democratización que el mercado habría promocionado desde el acceso al consumo y la fusión cultural. A propósito de un sonado caso de discriminación racial — Los Malditos de Larcomar-que complejizaba además variables de clase, status y posiciones geográficas en la gran Lima, León identificaba con insatisfacción una serie de cadenas de hibridación vinculante que habrían suturado lo dominante y lo residual de la cultura limeña y nacional. El caso contrastaba con un clima en el cual parecía haber menos discriminación, la gente se hacía respetar cada vez más, y las instituciones vigilantes de derechos humanos podían defenderlas mejor frente a las prácticas endémicas de maltrato. Así, el mercado funcionaba como escenario narrativo de encuentros virtuosos entre diferentes y compactaba desde su soporte de consumo, tradición y modernidad, indigeneidad y mestizaje: chullos y bellas modelos occidentales, bips electrónicos y ritmos populares, cantantes vernaculares en balnearios de clase alta, productos autóctonos en restaurantes gourmets, etc. Estos intercambios nos muestran las lógicas dinámicas de las interrelaciones del poder simbólico neoliberal, que ahora comenzaban a asignar un valor predominante a sujetos, objetos y significados que antes estuvieron ocupando un lugar residual en la cultura. Este desplazamiento genera nuevos lugares de emergencia que Raymond Williams $(1980,145)$ ha expresado así:

Un elemento cultural residual se halla normalmente a cierta distancia de la cultura dominante efectiva, pero una parte de él, alguna versión de él -y especialmente si los residuos provienen de un área fundamental del pasado- en la mayoría de los casos habrá de ser incorporada si la cultura dominante efectiva ha de manifestar algún sentido en estas áreas. [...] Es en la incorporación de lo activamente residual - a través de la reinterpretación, la disolución, la proyección, la inclusión y la exclusión discriminada - como el trabajo de la tradición selectiva se torna especialmente evidente. [...] Por emergente quiero significar en primer término, los nuevos significados y valores, nuevas prácticas, nuevas relaciones y tipos de relaciones que se crean continuamente, sin embargo, resulta excepcionalmente difícil distinguir entre los elementos que constituyen efectivamente una nueva fase de la cultura dominante, y los elementos que son esencialmente alternativos o de oposición a ella: en este sentido emergente antes que simplemente nuevo. Desde el momento que nos hallamos considerando permanentemente las relaciones dentro de un proceso cultural, las definiciones de lo emergente, tanto como de lo residual, solo pueden producirse en relación con un sentido cabal de lo dominante. 
La hibridación estratégica del diseño cultural publicitario propone que la intercambiabilidad de las mercancías y su capacidad de amoldamiento a usos y situaciones de consumo situadas, expresa un acercamiento físico y moral entre diversos polos sociales y culturales. Si antes la cultura era un espacio de sofisticación y diferenciación de estratos, ahora el mantra comunicacional va a proponer una amalgama incluyente que expresaría una nueva plataforma de diálogo e integración. Este lugar de homogenización asociado al gerenciamiento del multiculturalismo - un discurso que incorpora selectivamente lo residual-cultural, pero con cierta distancia dominante, excluyente y condescendiente frente al campo popular - se ha construido como imperativo hegemónico en la cultura que el neoliberalismo ha diseñado e inoculado estratégicamente en las audiencias nacionales. ${ }^{6}$ Hoy en día la triangulación entre el nacionalismo, el multiculturalismo y el amplio marco de exigencias de la globalización — su desregulación financiera, sus flujos agresivos de información, sus grandes diásporas y la difuminación de las fronteras nacionales, etc. - no plantean necesariamente la desaparición material del Estado-nación, sino que confirman que es todavía dentro de sus márgenes donde se siguen construyendo y estabilizando las diferentes identificaciones colectivas. La nación no se disuelve en la globalización, sino que se resignifica desde los imperativos culturales del mercado, que atados al afecto primordial, generan una perdurabilidad intermitente de las emergencias e interpelaciones nacionalistas.

Más que la necesidad de propiciar lugares y mecanismos de encuentro participativo, enunciación cívica - lugares materiales e infraestructuras institucionales de intercambio y disputa-, una de las manifestaciones que mejor ha organizado la relación de los sujetos con los ideales colectivos de la nacionalidad en los últimos años ha sido la promoción y defensa del consumo. Este es un soporte ineludible de relaciones humanas por el cual la gente se hace consciente de sus condiciones históricas de vida, participando desde la lógica del consumidor informado y vigilante. "Lejos de constituir tipos ideales aislados, el ciudadano y el consumidor fueron categorías de continuo desplazamiento que a veces se superpusieron y a menudo entraron en tensión, pero que

6 Hasta hace poco tiempo, el folklore y la cultura migrantes eran resistidas por las elites. A diferencia de la actual glorificación de la hibridación, en un inicio, "El redescubrimiento del universo migrante, y la mercantilización de la producción artesanal y musical, trajeron a la luz comportamientos y patrones de consumo cultural que fueron vistos, o como expresión de la nueva identidad popular (y nacional) o como una degradación del gusto" (Roel 2000, 96). 
en todo momento reflejaron la permeabilidad de las esferas de la política y la economía" (Cohen 2005, 8). ${ }^{7}$

Para efectos de este trabajo, el consumo cotidiano y aparentemente banal también debe ser leído como un gatillador de diversas experiencias y deseos de identificación simbólica que actualizan ética y emotivamente relaciones, filiaciones y fidelidades a ciertos productos, corporaciones e ideales, en la medida en la que remontan a las personas a una red de significantes biográficos que se apegan a las mercancías a lo largo del tiempo. La percepción de pertenencia colectiva es expresada por las personas en términos de una empatía que se profesa por objetos y productos materiales con significado histórico. Por ello, las corporaciones nacionales, sus líneas, productos y marcas históricas se invisten en la consideración de las gentes también a través de un vínculo de amor filial y fraternal.

Tomemos un breve recuento etnográfico sobre un seminario en el que los estudiantes de publicidad de una universidad limeña privada eran adiestrados en cómo las grandes corporaciones nacionales debían construir sus perfiles y estrategias desde el reconocimiento de las pulsiones afectivas de los consumidores. La identidad subjetiva era explícitamente atada a contenidos biográficos particulares (el migrante, el desplazado, el pobre, el solidario, el creativo, el recursero, etc.), pero que deben ubicarse además dentro de un relato histórico mayor, de carácter público y aspiracionalmente aglutinante. Mi traducción etnográfica consistió en la descripción e interpretación de documentos internos de planeamiento estratégico y posicionamiento de marcas que los agentes de marketing de algunas empresas peruanas históricas — Backus, Gloria, Inca Kola, E Wong, D’Onofrio, Field, etc.- presentaban a los futuros publicistas desde el paradigma publicitario de las lovemarks: productos, marcas y empresas que por su perdurabilidad histórica e icónica han pasado a la consideración afectiva de los consumidores nacionales.

También tomamos algunos ejemplos de estas estrategias, tácticas y diseños simbólicos para explicitar cómo la interpelación afectiva de la comunicación neoliberal organiza un relato, que a pesar de presentarse desde el terreno de la neutralidad política, está enunciado desde una intencionalidad ideoló-

7 En los Estados Unidos, la consolidación de la ciudadanía como categoría ético-política dependía del papel que jugaron las diversas asociaciones y gremios de ciudadanos-consumidores, en la defensa de sus derechos, exigiendo precios justos, mercancías de calidad, condiciones de empleo dignas para los trabajadores de las empresas y marcas que compraban, entre otros. 
gica. Por ejemplo, en la campaña de promoción de Nestlé para los productos históricos de la lovemark D’Onofrio — comprada por la corporación—, los creativos publicitarios parten del reconocimiento de un devenir histórico contemporáneo traumático. Primero se elaboran lluvias de ideas y especulaciones sobre los anhelos y deseos insatisfechos de comunalidad de la gente, se utilizan categorías políticas y antropológicas como nación, modernidad, progreso y etnicidad. Así, el consumidor puede ser un desplazado o un migrante internacional que, al probar un chocolate sublime, remueve memorias y vivencias tempranas que lo remontan a un Perú sufriente, pero que el propio consumo del producto encamina hacia la cura. Se combina un discurso de eficiencia con uno humanista, una lucha de superación, pero dentro de un esquema de auto-gerenciamiento y disciplinas individuales para afrontar un futuro que debe construirse.

Bajo esa misma lógica, los creativos de Backus enmarcan la narrativa de un spot publicitario de cerveza desde el voluntarismo creador del individuo moderno, quien debe liberarse de una fuerza colectiva o un azar providencial que transformará las cosas, para ponerse a trabajar, sin esperar ayuda o asistencia de nadie. Como el propio spot presentado enfatiza, la única forma de lograr un logro personal exitoso en el amor, en la movilización social y económica, en el trabajo, etc., implica entregarse a un plan estratégico e individual de vida. Ese plan parece eliminar todo rezago de confianza asociativa y recae en una voluntad aislada que debe traducirse en potencialidad, empeño y esfuerzo. El sujeto en soledad debe empoderarse y abrirse al futuro en busca de objetivos precisos. "Hay que sudarla para conseguirlo [...] el que la sigue la consigue". Sin embargo, a pesar del énfasis en la autonomía del individuo, el texto no pude dejar de dar un salto a la esfera comunal. La idea es ampliamente conocida: en la medida en la que te despiertes todos los días para aportar lo que debes aportar, el colectivo se retroalimenta: "Si tú despegas, el país despega". De esta manera, el sujeto es dueño de sus actos y destino, y no existe condicionamiento alguno que lo pueda limitar o detener. Ni económico, ni social, ni natural. ${ }^{8}$

El encubrimiento, la represión o la desmentida han sido las estrategias dominantes de la publicidad nacionalista en el Perú. Veamos cómo se devela su lugar de enunciación parcial —ideológica— desde el análisis de un grupo de spots trabajados para el Banco Continental basados en la épica de la solidaridad en la que el banco y sus inversionistas gastronómicos sostienen

8 Para observar un ejemplo de publicidad, véase https://www.youtube.com/watch?v=weeHNI4vsSs. 
virtuosamente la cadena productiva — de trabajo - que los dota de insumos (agricultura, pesca, transporte, servicios, etc.). La narrativa instrumenta la complejidad de la integración regional tratando de romper con las dinámicas excluyentes entre centros y periferias, pero develando una relación instrumental que congela a los productores regionales en esa tarea permanente de provisión y despensa que separa desigualmente a los actores del mercado a lo largo de la cadena de suministro. Se visibiliza esa circulación virtuosa de alimentos en las mesas de restaurantes cosmopolitas, mientras se oscurece el espacio de las condiciones materiales de producción de los trabajadores. Como Stuart Hall (2010) lo ha anotado, la explicación marxista del circuito capitalista no niega el mercado, lo analiza desde otra perspectiva. La narrativa publicitaria del spot analizado resalta de hecho una cadena del mercado exitosa muy real e innegable. Su problema es que solo registra una parte del circuito general en donde se producen las mercancías, y además lo hace idílicamente:

Si en nuestra explicación solo privilegiamos un momento y no tomamos en cuenta la totalidad o el conjunto diferenciado del cual forma parte, o si usamos categorías de pensamiento que son apropiadas para uno de tales momentos para explicar el proceso entero, entonces estamos en peligro de dar lo que Marx hubiera llamado una explicación unilateral [...] estas son siempre una distorsión. No en el sentido de que son una mentira sobre el sistema, sino en el sentido de que una verdad a medias no puede ser la verdad completa sobre nada. Con esas ideas solo será representada una parte de la totalidad. Así se producirá una explicación que es solo parcialmente adecuada, y en ese sentido, falsa. Además si solo se usan las categorías y los conceptos de mercado, para entender el circuito del capital como una totalidad, hay literalmente muchos aspectos de él que no se podrán ver. En ese sentido, las categorías de intercambio de mercado ocultan y desconciertan nuestro entendimiento del proceso capitalista: esto es, no nos permiten ver o formular otros aspectos invisibles. [...] La falsedad surge, por lo tanto, no del hecho de que el mercado sea una ilusión, un engaño, un truco, sino en el sentido de que es una explicación insuficiente de un proceso (Hall 2010, 144-145).

El encubrimiento ideológico que el spot hace del circuito del mercado solo privilegia momentos particulares: la circulación de insumos y el consumo final, dejando de lado el circuito de producción real de las mercancías culinarias y sobre todo las condiciones materiales y humanas de trabajo en donde además están involucradas relaciones desiguales de intermediación entre los productores. Entonces, hacer pasar explicaciones parciales (verdades a medias) por una verdad totalizante, camuflada idílicamente, puede aplicarse a la lógica general de la publicidad, a un juego entre la sobreexposición de las vir- 
tudes y el oscurecimiento de las faltas o perversiones de los objetos, servicios o discursos publicitados.

Por su parte, los ejecutivos de Inca Kola presentan una línea del tiempo de la realidad nacional peruana de los últimos setenta años identificando la vida de la marca con los procesos de cambio social que el país ha experimentado. En diversos cuadros y cronologías histórico-dialécticas, la marca asume una condición espiritual de la peruanidad que se auto-realiza en cada etapa histórica. Rememorando el historicismo hegeliano, la empresa asume el devenir histórico como necesario, mutando funcionalmente y adaptando sus conveniencias estratégicas como empresa a cada momento de clivaje sociopolítico: el estatismo colectivista velasquista, en donde el slogan "de sabor nacional" acompaña la revolución, pero también desde "Combina con todo", expresando una nueva refundación basada en la reconciliación de razas y clases, y que podemos ejercer en el contexto de la convivencia multicultural neoliberal. La empresa que ya había sido vendida a un grupo internacional se define como un ente de articulación con responsabilidades de representación e intervención pública, nominándose explícitamente como eje del desarrollo nacional en un contexto además de abandono de lo público y de presión permanente frente al sector privado de performar en tanto sustituto del Estado.

Finalmente, los ejecutivos de Movistar presentan un paquete de spots que serán publicitados en señal abierta progresivamente durante un año. El sentido de los mismos apunta a sobreexponer el conflicto y las dificultades nacionales, pero para proponer mensajes de integración y colaboración entre sujetos sociales diversos. Se plantean así narrativas que reconocen la fractura y el dolor de nuestra separación, enmarcadas en investimentos visceral-afectivos que, sin encubrir la dimensión antagónica de la construcción nacional, se entregan a la positividad utópica del amor fraternal entre diferentes. El spot "Un lunes cualquiera" es un buen ejemplo de esto:

Un lunes cualquiera nos despertamos, hacemos un par de cambios, recuperamos el tiempo, lloramos; un lunes cualquiera nos detenemos, nos entendemos, encontramos la fórmula y acertamos; un lunes cualquiera corremos un riesgo cualquiera, lo hacemos por los "otros", que es lo mismo que "nosotros". Porque todo rima un lunes cualquiera, y cuando comenzaremos a vernos con los demás, desayunados todos, al borde de una mañana eterna. Un lunes, señor Vallejo, un lunes cualquiera, en que entendemos lo que fuimos, y entendemos lo que seremos. Y oiga, usted, ¿en qué momento se enderezó el Perú? Un lunes, Zavalita, un lunes cualquiera, en que comenzamos una conversación, y nunca más la terminamos. Un lunes en que nos acostamos peruanos y amanecimos hermanos. 


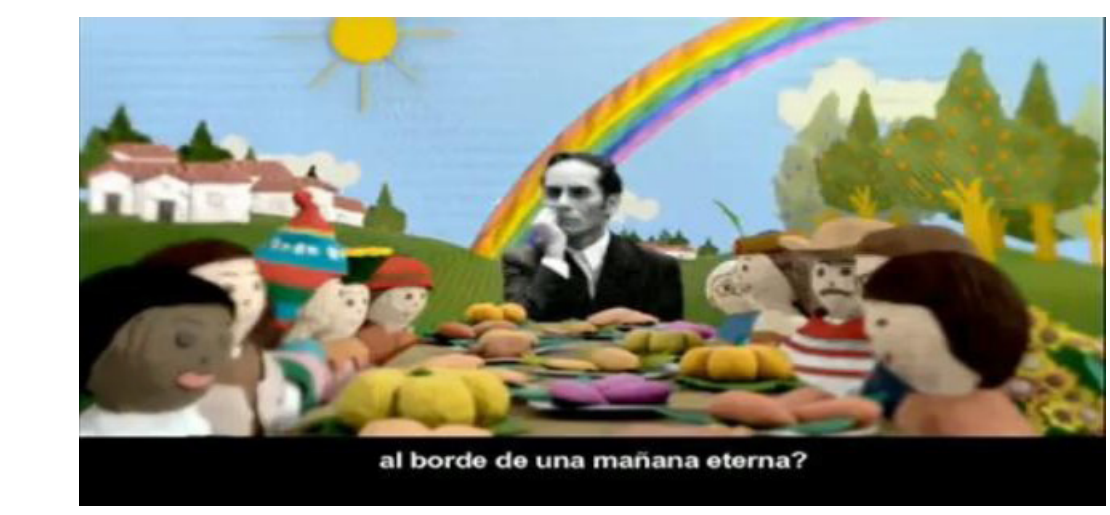

IMAGEN 6. Captura de imagen del video publicitario titulado "Un lunes cualquiera", elaborado por Young \& Rubicam para Movistar (2009).

La retórica del drama construye un simulacro re-constitutivo de solidaridad y comunión aspiracionales, cierta melancolía vergonzante que funciona como un gancho mimético invitando a las audiencias a preguntarse si los antagonismos podrán afrontarse. En la medida en que no sabemos cuándo llegará ese lunes cualquiera, ni cómo lo haremos, se elimina explícitamente el proceso, es decir, la necesidad de la política. De alguna manera se nombra el conflicto, pero para pasteurizarlo. El texto precedente, narrado desde una voz en off, es acompañado por acordes menores de guitarra que contrapuntean sobre imágenes que capturan nuestra atención anímica. La secuencia visual que acompaña al texto es como sigue: una combi frena y cede el paso a un peatón; un plato es compuesto por distintos potajes peruanos característicos; la surfista Sofía Mulanovich alza una bandera y celebra un triunfo; una jugada de voleibol excepcional a favor del equipo peruano; un actor que representa a Vallejo en su típica caracterización reflexiva preside una mesa en medio de montañas coloreadas (en animación y montaje), en donde están sentados de un lado una colección de subalternidades: diversos personajes mestizos, indígenas y afros en ropas típicas. Enfrente están los mistis blancos.

Es precisamente aquí cuando la narración evoca el desayuno colectivo "al borde de una mañana eterna". La estética del dibujo-montaje en esta sección juega a la promesa de unidad dentro de la diferencia. Si bien todos los muñecos están vestidos y pigmentados de forma diferente, su masa corporal denota que son el mismo sujeto. De hecho, la caracterización de estos personajes en la mesa nos muestra el molde típico de los muñecos de los 
juegos para armar de playmobil, en los que una misma pieza puede adoptar presentaciones y labores infinitas en la sociedad que recrea. Por ello han sido reconocidos por su pluralidad racial, sexual, etc. Entonces la diferencia expresada en la serialización de la estética playmobil es, en algún sentido, la integración en un solo cuerpo colectivo, en una nueva soldadura humana. Pero recordemos que la imagen aparece en el spot solo un par de segundos, por ello prosigamos con su estructura. Le sigue una secuencia multicultural básica, un niño negro, una niña rubia casi albina, una niña trigueña, un niño oriental, una niña mestiza y un niño amazónico. Luego aparece la figura de un tecnócrata mostrando las curvas de lo que puede interpretarse fue el declive de la producción peruana bajo regímenes de desarrollo anteriores. Se observan curvas decrecientes. Aquí la imagen contrapuntea con el texto del spot que dice "Debemos conocer lo que fuimos". Seguidamente, el texto alude a lo que somos y seremos, es decir, al momento actual del país, mostrando detrás del tecnócrata una curva ascendente que denota el crecimiento de la producción nacional. Finalmente, en otro corte abrupto de edición, el clímax del comercial nos muestra a una pareja llegando al aeropuerto Jorge Chávez de Lima, quienes son esperados por sus familiares con una banderola que dice: familia Zavala. El narrador pregunta: “¿Y cuando se arregló el Perú, señor Zavalita?”.

Un elemento técnico importante del recurso dramático del spot es su poder de desplazamiento entre eventos y su capacidad de condensación de significados y pulsiones. La cantidad de información y su plataforma de emisión compulsiva, acompañada de notas melancólicas, no pueden posicionarse con claridad racional en el espectador - además, la información es transmitida en alrededor de cincuenta y tres segundos- El bombardeo frenético de edición de imágenes, cruzado con el audio en quechua, el texto en castellano y la música triste genera un golpe anímico en el público, que no termina de entender si está visionando un reclame comercial, un spot de la teletón o un documental, etc. Es solo entre los últimos tres segundos que aparece el logo de Movistar y Telefónica haciendo su tímida revelación publicitaria: "Movistar, conectados podemos más", casi al punto de velar el logo de la empresa y su posición de anunciante.

Entonces, al no hacer ninguna referencia explícita al producto que ofrece, a las calidades de su servicio, o alguna oferta o plan novedoso, Movistar desplaza la percepción del sujeto en la pulsión afectiva. Pero si la pregunta que eleva el spot es si algún día podrán los diversos grupos sociales, geográficos y 
regionales convivir respetuosamente bajo una condición ciudadana y un paradigma de respeto y empatía, la respuesta está dada ya en el mismo spot, pero desde el soporte de la igualación desde el modelo del crecimiento económico y su estabilidad macro. Por ello, el fatalismo de Zavalita, un personaje criollo quejoso de la transformación de la composición social peruana - una realidad desbordada, jodida y contaminada-, es ahora identificada por Movistar desde el convencimiento del peruano que regresa y confía nuevamente en el país. Ese ícono de ficción literaria, que dio una extremaunción a la sociedad criolla limeña, invadida por las masas migrantes que desestabilizaron el orden tradicional y letrado de la ciudad (desde la valoración de Vargas Llosa), es ahora quien acepta y abraza el nuevo momento de refundación nacional, en el horizonte neoliberal. Si la idea de modernización de Vargas Llosa implicaba un franco proceso de asimilación de arriba abajo entre la modernidad criolla y los valores de la tradición andina y el mundo subalterno, en general - esos valores debían ser preferiblemente desterrados_-, ahora el imperativo dominante exige una traducción armoniosa y selectiva entre lo local y global, entre lo originario y lo cosmopolita, pero con una inclinación estratégica a los intereses económicos del empresariado nacional y los sectores modernizados por el modelo. Si bien el Premio Nobel reconoce y celebra la ascendencia de una burguesía migrante en la ciudad, su mirada sobre la modernidad y su vinculación con el mundo andino ha estado atravesada por la necesidad de homogenización eurocéntrica, con la modernización de lo arcaico o su destierro. ${ }^{9}$ Sus recientes declaraciones en contra de lo que representa el candidato presidencial Pedro Castillo, un indígena-mestizo, privilegian el soporte del mercado sobre la compleja infraestructura cultural y regional — situadasque componen los fragmentos negados de lo nacional. Las imágenes 8 y 9 del spot "Conectados" de Movistar son una constatación sintomática de ese eurocentrismo modernizante y multicultural ya referido, que la promesa engañosa de la publicidad integracionista no puede cumplir. En la primera, un campesino mestizo peruano es "hablado" por un blanco criollo, que le extiende su ayuda y capacidad de representación para no dejarlo en el silencio; en la segunda, se representa la cohesión virtuosa entre la tradición y la modernidad occidental con la sustancialización de la llama andina y el caballo europeo galopando armónicamente.

9 Este es el primero de una serie de spots publicitarios de Movistar, que bajo la misma lógica de remoción afectiva estuvieron al aire en horario estelar, entre los años 2010 y 2012. 


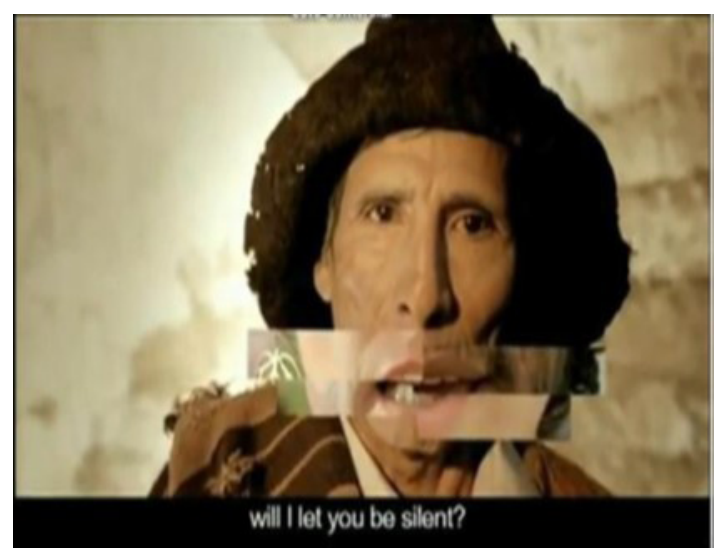

Imagen 7. Captura de imagen del video publicitario titulado "Conectados", elaborado por Young \& Rubicam para Movistar. 2010.

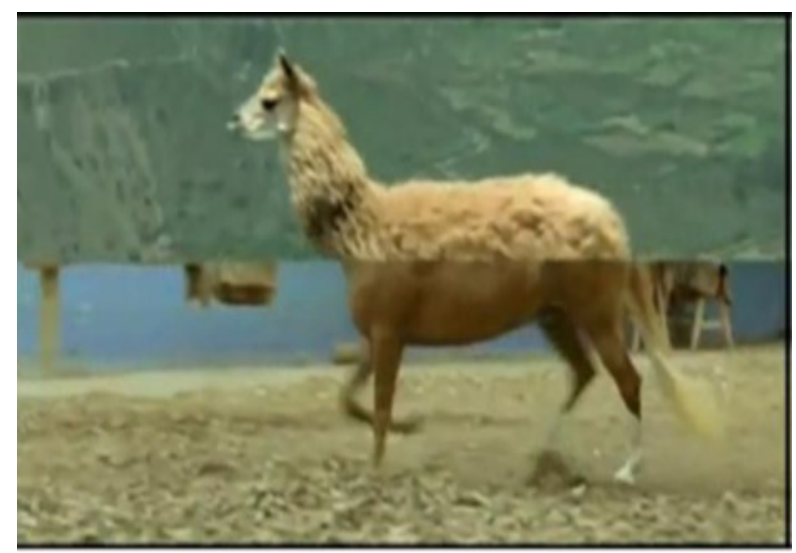

Imagen 8. Captura de imagen del video publicitario titulado "Conectados", elaborado por Young \& Rubicam para Movistar. 2010.

Es bajo este andamiaje discursivo que las empresas y sus mercancías han sido calificadas por su rendimiento, la satisfacción coste-beneficio que producen, pero también por sus declaraciones y compromisos de responsabilidad social, dotando de una estructura instrumental-sentimental a sus productos, dándoles vida y contenidos peculiares. Pero como hemos visto, sin investimento primordial, libidinal, afectivo, no hay entramado discursivo, performativo y conductual que se asiente. Así, las mercancías pasan de ser un mero "objeto de deseo" a convertirse en un acompañante del proceso vital e histórico del ciudadano-consumidor. Como señala Marx $(1986,3)$ en las primeras líneas de El capital, las mercancías son objetos externos al sujeto, cosas 
que sirven para satisfacer distintas necesidades. "De cualquier clase que ellas fueran [...]. El carácter de estas necesidades, el que broten por ejemplo del estómago o de la fantasía no interesa en lo más mínimo para estos efectos". De esta forma, Marx comprendía claramente la vinculación múltiple de la satisfacción que otorgan las mercancías, las cuales exceden su función primaria de satisfacción biológica del hombre (alimento, vestido, etc.), abriéndose dúctilmente al terreno de la satisfacción simbólica e imaginaria, asentada en la visceralidad del deseo afectivo de completud.

De esta manera, la publicidad nacionalista funciona como un fantasma, en el sentido que otorga la promesa de recubrimiento de nuestras faltas al entregarnos paliativos y armonías parciales, pero que nunca nos podrán conducir a una experiencia de gratificación total, porque esta es imposible. Stavrakakis $(2010,270)$ lo expresa de la siguiente manera:

El universo publicitario proyecta toda experiencia de la falta en la falta del producto publicitado, es decir, en una falta que puede evadirse con una simple maniobra: la compra del producto, el acto de consumo [...]. Pero aquí se hace imperioso no pasar por alto el hecho de que precisamente porque somos incapaces de recobrar nuestro goce pre-simbólico perdido/imposible en toda su plenitud, el fantasma publicitario intenta exorcizar el malestar de la vida cotidiana mediante la reproducción del sistema del cual ese malestar es constitutivo. El deseo solo puede sostenerse mediante la dialéctica de la falta y el exceso; a fin de conservar su atractivo, la promesa del exceso descansa sobre la renovación continua de experiencias de falta.

Pero si las estrategias publicitarias que construyen fantasías y ofrecimientos de completud nunca podrán darnos la satisfacción plena, ¿cuál es entonces su funcionalidad? Pues disciplinarnos en el deseo compulsivo de completud. Una tarea imposible, pero que organiza una agenda de programación conductual y prácticas económicas de consumo, atadas a formas culturales de autoproducción ideal. Nuevamente, es claro que la dimensión discursiva es crucial para estructura un régimen de deseos y performances; sin embargo, la inscripción de los discursos no es suficiente para sostenerlo, la realidad de nuestros cuerpos siempre está atada a un componente material. Como indica Jusdanis $(2001,31)$, "Las referencias al sentimiento, la actitud y la lealtad ponen de relieve la dimensión extremadamente visceral de la identidad. El nacionalismo funciona a través del corazón, los nervios y las tripas. Es una expresión de la cultura que atraviesa el cuerpo". Esa visceralidad no puede escapar del hecho de perseguir el deseo de completud nacional desde el sacrificio romántico 
sin, al mismo tiempo, poder renunciar a identificar un fantasma nacional al cual odiar, sea este externo como interno. Esto último se hace se hace patente cíclicamente, volviendo a emerger en el contexto actual de elecciones de segunda vuelta, cuando se personifica desde el discurso hegemónico modernizador y limeño a una otredad primitivizada y colectivista, aquellos peruanos periféricos que manifiestan sus preferencias por un reemplazo radical de los protagonistas en el control del poder gubernamental y la toma de decisiones. Un gran espacio regional indígena-mestizo que es congelado y estigmatizado en el tradicionalismo conservador y comunitario, desde lo que Ubilluz (2009) ha llamado el fantasma de la nación cercada.

\section{Monopolio privado del campo simbólico, abandono constitutivo de lo político. A manera de conclusiones}

Más allá de ser considerado como un lugar de manipulación banal, la cultura comunicacional y publicitaria contemporánea es un potente espacio desde donde se construyen y fijan significados ideológicos. Comprendiendo las lógicas subjetivas que se debaten entre la falta y el exceso, ha sabido enquistar sus construcciones simbólicas e invitaciones performativas, en la visceralidad afectiva de los sujetos. Desde esa maquinaria, los dispositivos generados desde la alianza explícita entre el Estado, el empresariado y las industrias publicitarias han sedimentado en las dos últimas décadas la alineación de la nación a los criterios económico-culturales del neoliberalismo. Así, la producción retórica de imágenes ha pretendido nombrar, imponer y re-imaginar la nación solo desde el modelo del libre mercado, el crecimiento económico y la unificación utópica sin conflicto. En este nuevo momento crítico para forjar la comunidad política, la situación se hace más urgente porque la imagen y los signos alrededor de ella son fundamentales para reproducir las creencias sociales y construir consensos hegemónicos. Hoy el dominio ya no es solo una cuestión de propiedad de los medios de producción, es también un control sobre los discursos y las imágenes.

En este sentido, el proyecto bicentenario se perfiló como un intento deliberado por desmarcarse de las estrategias gastro-políticas de los organismos de promoción productiva y comercial del Estado. Al trasladar decididamente al espacio intelectual la responsabilidad de componer un relato renovado de identificaciones y tareas colectivas pendientes, el proyecto ha esbozado algu- 
nas actividades e intervenciones situadas que dan protagonismo a la academia y la gente común desde una perspectiva descentralizada. El volumen y el valor de sus archivos documentales será invaluable. Sin embargo, la actual intersección de múltiples crisis ha limitado y opacado severamente su accionar, impactando la recepción ciudadana de sus productos. Asimismo, en todas sus actividades publicadas a través de sus canales institucionales — charlas de intelectuales, ponencias de ciudadanos en regiones, productos y series temáticas en RTV, etc. - hay una excesiva presencia, voz y formato letrado. Si la idea de la cátedra bicentenario es iluminar el pasado para encarar el futuro, dándole un peso de excepción a los historiadores, la pregunta sería como traducir la bastedad de ese repositorio académico en términos divulgativos, impactando en el ciudadano común, en los científicos sociales y en los servidores públicos. De hecho, es sintomático que muchas de las cátedras renueven el interés historiográfico por el rol del mundo popular durante el proceso emancipatorio: los actores políticos regionales con racionalidades propias, intereses particulares, pero también nacionales; el estudio de los niveles locales y los ayuntamientos; el centralismo y la regionalización; el federalismo, etc. Todas estas líneas de investigación que cuestionan el sistema unitario de gobierno, el presidencialismo personalista y la democracia electoral representativa, desde distintas temporalidades y espacialidades, están presentes y reprimidas desde el inicio de la república, en tanto líneas de reforma que nunca han terminado de ser agregadas en una agenda de discusión política efectiva, siempre licuadas por el centralismo criollo limeño y las formas de representación vertical y administrativa de la democracia liberal.

Como he mostrado desde el análisis visual crítico, las reformas neoliberales modernizaron parcialmente procesos institucionales y productivos, con el costo de vaciar al aparato del Estado de su dominio sobre el espectro amplio de lo público (prestación de servicios materiales), pero sobre todo de su rol cohesionador a partir de políticas de articulación simbólica (ciudadana), desplazando la relación entre culturas públicas, acción colectiva y ciudadanías situadas. Al delegar en las tecno-burocracias de expertos la toma de decisiones, el rol del Estado se ha acotado a una función de administración gerencial de autoridad macroeconómica, que coopta primero y abandona paulatinamente tanto relaciones directas y mediadas con una multiplicidad de agentes subalternos autonomizados y asociativismos dispersos, que al mismo tiempo han mantenido y dinamizado vidas organizativas en las escalas barriales y comunales. A pesar de las consecuencias del legado patrimonial fujimorista, sus 
cambios y continuidades a través del proceso de descentralización, y la necropolítica producida por el conflicto armado interno, las diversas acciones colectivas de las microescalas local-populares han permanecido activadas bajo variadas sociabilidades urbanas, civiles, indígenas, disidentes, pedagógicas, etc. En este contexto, el diseño institucional político, si bien necesario, es insuficiente para movilizar ciudadanos críticos, activos e informados, sobre los cuales cementar democracias radicalmente localizadas en prácticas cotidianas y culturas políticas en disputa. Por ello, parte de este trabajo ha pretendido visibilizar el gran vacío que el Estado, en tanto aparato ideológico y educativo — de promoción y construcción de identidades sociales-, ha cedido a tutela y exclusividad del campo simbólico privado. A pesar de ello, tarde o temprano, como constatamos hoy en día, la realidad crítica aflora y disloca el consenso tecno-científico y burocrático naturalizado por las comunicaciones masivas como verdad indisputable. De hecho, esa es la finalidad de la ideología: cerrar los significados, fijarlos, clausurar el debate y acotar quienes acceden a él. Por esta razón, es importante recordar brevemente un aserto básico de los paradigmas científicos, y es que la ciencia y la técnica normalizadas - un paradigma económico, por ejemplo - tienen poca memoria, ya que su normalización nunca está garantizada ni a salvo. Siguiendo a Khun, siempre será dependiente de las crisis y las revoluciones epistemológicas, que traen nuevos órdenes de discursos y perspectivas que hacen que la construcción del conocimiento situado nunca sea suficiente y siempre se le escape algo. De ahí su provisionalidad sujeta a la disputa inacabada.

Bajo esta constatación, se hace imperativo abrir nuevas condiciones de posibilidad para la relación entre Estado y sociedad. ¿Será acaso posible superar el formalismo legal de las leyes de participación ciudadana, para dotarlas de valor vinculante, por ejemplo, en los mecanismos de participación que demandan la presencia activa de los ciudadanos en los cabildos y consejos municipales? ¿Es posible expandir las lógicas asambleístas en los espacios locales bajo esta misma investidura vinculante? ¿Cómo se podría repensar y reposicionar el rol del Estado, a partir de sus potenciales relaciones con las comunidades situadas y sus respectivas representaciones de lo nacional? ¿Cómo en una época de consenso privatizador tardío, el Estado puede reclamar el derecho de asegurar políticas simbólicas y culturales para los históricamente excluidos con el fin de generar otros consensos hegemónicos? ¿Cómo en un momento de re-evalución del modelo privatista de la economía, el Estado puede remodelar un nuevo equilibrio hegemónico con el mercado? 
¿Cómo contaminar la categoría liberal del ciudadano distante y reemplazarla con la de un nuevo tipo de vecino participativo anclado en la distritalización? Y más, precisamente, ¿cómo una participación agresiva del Estado en la recuperación, mantenimiento y gestión de espacios de encuentro y disputa puede contribuir a generar un modelo fluido que suscite alfabetizaciones críticas que puedan dialectizar, como significantes flotantes, las memorias nacionales inacabadamente? 


\section{Referencias bibliográficas}

Barthes, R. 1999. Mitologías. Ciudad de México: Siglo XXI Editores.

Bedoya, R. 2019. El cine peruano hoy. Cultura24.com.

Buntinx, G. 2003. Pintando el horror: sobre memorias de ira y otros momentos en la obra de Jesús Ruiz Durant. En M. Hamann et al. (Eds.) Batallas por la memoria: antagonismos de la promesa peruana (pp. 315-336). Lima: Fondo Editorial de la Pontificia Universidad Católica del Perú, Universidad del Pacífico, Instituto de Estudios Peruanos.

Cánepa, G. y Lossio, F. 2019. La nación celebrada: marca país y ciudadanías en disputa. Lima: Universidad del Pacífico, Fondo Editorial de la Pontificia Universidad Católica del Perú, Cultural Narratives of Crisis y Renewal.

Cánepa, G y Lamas, L. (Eds.). 2020. Épicas del neoliberalismo: subjetividades emprendedoras y ciudadanías precarias en el Perú. Lima: CISEPA, Fondo Editorial de la Pontificia Universidad Católica del Perú.

Cant, A. 2017. Representando la revolución: la propaganda política del gobierno de Juan Velasco Alvarado en el Perú, 1968-1975. En S. Schuster y D. Hernández (Eds.) Imaginando América Latina. Ensayos de historia y cultura visual, siglos XIX y XX. Bogotá: Universidad del Rosario.

Chatterjee, P. 2007. La nación en tiempo heterogéneo. Lima: Instituto de Estudios Peruanos, SEPHIS.

Cohen, L. 2004. A Consumers Republic: The Politics of Mass Consumption in Postwar America. Nueva York: Vintage.

Laclau, E. 2005. La razón populista. Ciudad de México: Fondo de Cultura Económica.

La Lucha. 2010. Fidel [encarte]. Lima

Leonardini, N. 2009. Identidad, ideología e iconografía republicana en el Perú. Arbor. Ciencia, Pensamiento y Cultura, 185 (740), 1259-1270.

Heath, J. y Potter, A. 2004. Nation of Rebels. Why Counterculture Became Consumer Culture? New York: Harper Collins Publishers.

Herzfeld, M. 1991. A Place in History: Social and Monumental Time in a Cretan Town. Princeton, New Jersey: Princeton University Press.

Jusdanis, G. 2001. The Necessary Nation. Princeton: Princeton University Press.

Mc Evoy C. 2010. Armas de persuasión masiva: retórica y ritual en la guerra del Pacífico. Santiago de Chile: Centro de Estudios Bicentenario

Martin-Barbero, J. 2009. Comunicación, ciudadanía y espacio público en tiempos de globalización. Revista Foro, (71), 37-51.

Marx, K. 1986. El capital (t. 1). Ciudad de México: Fondo de Cultura Económica. 
Matta, R. 2016. Unveiling the Neoliberal Taste. Peru's Media Representation as a Food Nation. Revista Colombiana de Antropología, 40 (2), 15-40.

Mejía, V. 2007. Ilusiones a oscuras. Cines en Lima, grandes salas y multicines, 18972007. Lima: Biblioteca Nacional del Perú.

Méndez, C. 2000. Incas sí, indios no: apuntes para el estudio del nacionalismo criollo en el Perú. Documento de Trabajo 56, Serie Historia 10. Lima: Instituto de Estudios Peruanos.

Pantigoso, F. 2010. Conectados podemos más. Movistar.

Portales, A. 2009. Huáscar embotellado. Lima: autor.

Rodríguez, G. y Sánchez, C. 2002. Pisco peruano. Racimo de uvas. Lima: S \& S, Quorum Nazca.

Ruiz Durand J. 2018. Entrevista con Roberto Amigo. Museo Malba. https:/www.youtube.com/watch?v=370Ohu3Qm78

Schecner, R. 2002. Performance Studies. An Introduction. London, New York: Routledge. Smith, A. 2000. Nacionalismo y modernidad. Madrid: Istmo.

Stavrakakis, Y. 2010. La izquierda lacaniana. Psicoanálisis, teoría, política. Buenos Aires: Fondo de Cultura Económica.

Ubilluz, J. C. 2009. El fantasma de la nación cercada. En Hibbett, A., Ubilluz, J. C. y Vich, V. (Eds.). Contra el sueño de los justos. La literatura peruana ante la violencia política. Lima: Instituto de Estudios Peruanos.

Young \& Rubicam. 2009. Un lunes cualquiera. Movistar. 